\title{
Dual Language Books Go Digital: Storybooks Canada in French Immersion Schools and Homes
}

\author{
Rahat Zaidi \\ University of Calgary \\ Robin Metcalfe \\ University of British Columbia \\ Bonny Norton \\ University of British Columbia
}

\begin{abstract}
In response to Canada's growing ethnic, cultural, and linguistic diversity, educators in French immersion classrooms are increasingly responding with enhanced cross-linguistic initiatives, and dual language books are promising resources in the promotion of multilingualism (Zaidi, 2020; Zaidi \& Dooley, 2021). This paper details a research project we completed in a 2019 classroom-based qualitative case study in a French immersion school experiencing an increasing enrollment of linguistically diverse students. The researchers sought to determine if Storybooks Canada, a free digital platform with 40 dual language books in multiple languages, could help promote literacy engagement and strengthen home-school connections. Five teacher participants identified a range of features that make the platform a useful resource for promoting literacy engagement, text comprehension, learner autonomy, meaning-making, and instructional differentiation. These included (i) the multilingual features, (ii) the ability to project stories on a large screen, (iii) the audio component, (iv) the illustrations, and (v) the different levels of text difficulty. While teachers made almost exclusive use of the French language features of the site, for classroom purposes, they supported cross-linguistic uses of the platform in the home context, with a view of strengthening home-school connections.
\end{abstract}

\section{Résumé}

En réponse à la diversité ethnique, culturelle et linguistique croissante présente actuellement au Canada, les éducateurs des classes d'immersion française y répondent de plus en plus en établissant des initiatives interlinguistiques améliorées. Par example, les livres bilingues sont des ressources prometteuses pour la promotion du multilinguisme (Zaidi, 2020; Zaidi et Dooley, 2021). Cet article détaille un projet de recherche réalisé en 2019 grâce à une étude de cas qualitative dans un école d'immersion française qui connait une augmentation du nombre d'élèves linguistiquement diversifiés. Les chercheurs ont cherché à déterminer si Storybooks Canada, un plateforme numérique gratuite avec 40 livres bilingues en plusiers langues, pourrait aider à promouvoir l'engagement en matière d'alpabétisation et à renforcer les liens entre la maison et lécole. Cinq ensignants participants ont identifié une gamme de caractéristiques qui font de la plateforme une ressource utile pour promouvoir l'engagement 
en littératie, la compréhension de texte, l'autonomie de l'apprenant, la création de sens et la différenciation pédagogique. Ceux-ci comprenaient (i) les fonctionnalités multilingues, (ii) la possibilité de projeter des hitoires sur un grand écran, (iii) la composante audio, (iv) les illustrations et (v) les différents niveaux de difficulté du texte. Bien que les enseignant aient utilisé presque exclusivement les caractéristiques en français du site, dans le cadre de la salle de classe, ils ont appuyé les utilisations interlinguistiques de la platforme dans le contexte familial, avec le but de renforcer les liens entre la maison et l'école.

\section{Dual Language Books Go Digital: Storybooks Canada in French Immersion Schools and Homes}

Among the diverse initiatives that support multilingual teaching in Canadian classrooms, dual language books have demonstrated considerable potential for building connections between school and home languages (Cummins, 2019; Darvin \& Norton, 2014). Dual language books have a story told in two languages, and studies have found successful cross-linguistic strategies using such books, specifically as they relate to literacy acquisition (Naqvi et al., 2012; Zaidi, 2018, 2020). Similarly, a digital story using a multilingual platform can leverage the linguistic resources of language learners (Lyster, 2008) and offer the opportunity to experience cross-linguistic transfer, in which students capitalize on strengths in their dominant language to support gaps in their nondominant language (Ballinger, 2013). This study sought to determine whether a new, freely available digital platform, called Storybooks Canada ${ }^{1}$, might serve as a useful pedagogical tool in French immersion classrooms and whether teachers thought it had potential for strengthening connections between linguistically diverse homes and schools.

Storybooks Canada is a free digital platform with 40 children's books available in 30 of the most widely spoken languages in Canada. Developed at the University of British Columbia, under the leadership of Dr. Bonny Norton, Storybooks Canada is the original modular site of the rapidly expanding Global Storybooks project ${ }^{2}$, whose vision of global multilingual literacy is shared on over 50 sites across five continents (Norton et al., 2020). By repurposing free illustrated stories from the African Storybook ${ }^{3}$ initiative, the Storybooks Canada digital platform seeks to promote multilingual literacy for young Canadians (Stranger-Johannessen et al., 2018). The site is designed to be user-friendly, with easy access on various types of digital devices. The toggle feature enables users to switch between French or English and one of 28 home languages, thus providing immediate access to 40 digital dual language books, most with audio. This feature enables Storybooks Canada to respond to Canada's changing demographics and the needs of an increasing number of linguistically diverse students who require support with language, literacy, and academic content. Helping these students meet their needs is a growing priority for school districts, and gives schools the opportunity to leverage the cultural and linguistic potential of diverse students in Canadian classrooms.

The present qualitative case study builds on other related studies (StrangerJohanessen \& Norton, 2017, 2019) to determine the extent to which Storybooks Canada might prove useful for both literacy engagement (Cummins, 2011) in increasingly diverse French immersion classrooms and for strengthening home-school connections, an emerging area of research in immersion programs (Gaudet, 2013; Pellerin, 2013). The 40 digital books in Storybooks Canada incorporate increasing levels of difficulty and are 
available in French and English, as well as the languages spoken most widely by immigrants and refugees new to Canada, including Mandarin, Cantonese, Punjabi, Tagalog, Arabic, and Somali. In addition to the toggle and audio features, users can also download the stories in different formats, e.g., dual language, wordless, imageless, and outline. Platform resources include a dedicated link for teachers with information on how the stories can be linked to curricula (Gilman, 2018; Gilman \& Norton, 2020).

The five-month study, conducted in 2019 , sought to address the following two questions: (a) What features of the Storybooks Canada digital platform can help promote literacy engagement in early French immersion programs? (b) To what extent did the teachers think that Storybooks Canada could strengthen connections between linguistically diverse homes and schools? Research on "literacy engagement", which includes a focus on enjoyment and enthusiasm for literacy (Cummins 2011, p. 144), has found that "highly engaged readers substantially outscored students who came from backgrounds with higher education and higher income, but who themselves were less engaged readers."

The article begins with an introduction to French immersion in Canada, explores current debates on the use of home languages and their cultural relevance in French immersion classrooms, and then addresses the role of parents in French immersion programs. After the research design is described, the central findings of the study are discussed, with a focus on our two research questions.

\section{Literature Review}

\section{French Immersion in Canada}

In the 1960s, French immersion programs took root in Quebec, in the context of the perceived social and economic advantages of bilingualism (d'Anglejan, 1984; Genesee \& Gándara, 1999; Lamarre, 1997), and then expanded to the rest of Canada. To date, a dominant French immersion ideology maintains that the boundaries between the first language (L1) and the second language (L2) should remain strictly entrenched, and that students and teachers should speak and use only the L2 (Lambert, 1984; Yu, 2000).

Increasingly, however, the notion of a purely input-driven L2 learning experience, so long advocated by French immersion proponents, is now being debated (Cummins, 2014; Swain \& Lapkin, 2013) and there has been an expanded interest in examining whether the student's L1 can play a more predominant role in the language learning process. This is being motivated by recent immigration trends in Canada, which have changed the demographics of many French immersion programs - historically dominated by Anglophone students. This has resulted in classrooms that are increasingly linguistically diverse (Davis, et. al. 2019; Mady, 2012; Mady \& Garbati, 2014; Roy, 2015). Some scholars like Swain and Lapkin (2013, p. 102) argue that "principled L1" use can contribute to the learning process by facilitating intake and helping multilingual students achieve success in immersion programs (Turnbull \& Dailey-O'Cain, 2009). Further to this argument, Swain and Lapkin (2000) concluded that "to insist that no use be made of the L1 in carrying out tasks that are both linguistically and cognitively complex is to deny the use of an important cognitive tool" (p. 269). Ballinger's (2013) research has indicated that schools must build programs that support bilingual or multilingual students' natural 
proclivity to translanguage, or to cross back and forth between languages, rather than building imaginary boundaries between those languages.

Indeed, some scholars have noted that the success of French immersion programs using only the L2 may have been somewhat stifled by limiting teachers' discussions of other languages within the classroom (Mady \& Garbati, 2014). Increasingly, the knowledge students possess of their L1 can be seen as a valuable asset, rather than an interference (Mady \& Garbati, 2014). In this spirit, Lyster et al. (2009), for example, found that resources such as bilingual readings are one mechanism by which students' overall understanding can be reinforced. Consistent with Lyster's (2009) work, the Storybooks Canada resource provides the opportunity for learners to enjoy reading in two or more languages.

Researchers are also exploring the role that culturally responsive pedagogy (CRP) can play with respect to use of the L1. CRP recognizes, identifies, and nurtures students' unique cultural and linguistic strengths to promote student achievement and well-being (Ladson-Billings, 1994). Apple (2012) and Gogolin (1997) remind us that today's classrooms have been largely developed and based on a monolingual and monocultural format, promoting what has traditionally been the dominant language and culture. In Canada, this has been English or French. The multilingual turn in classroom demographics in recent history has created a movement towards understanding the dynamic complexity of students' repertoires, and the way students can draw on this complexity for meaningmaking (Rymes, 2014). Otheguy, et. al. (2015) and Busch $(2012,2015)$ highlight the fact that students use various resources (linguistic, cultural, and multimodal) in a unified and interwoven manner that is dynamic, expanding and developing over the course of a lifetime. As a result, teachers and culturally diverse students are encouraged to develop strategies not only to sustain cultural practices and affirm a student's particular home language but also to encourage acceptance and respect of self and others. This gives educators, students, family, and community a sustainable vivre ensemble (Prasad \& Lory, 2020) with the language(s) of instruction. In effect, a resource such as Storybooks Canada, with all its multilingual possibilities, allows for a "linguistic complicity" where the languages present in the students' repertoire become a source of pride.

\section{The role of Parents in French Immersion Programs}

Typically, French immersion parents place a high value on education, perceiving the ability to speak another language as a strong asset for success in life (Dagenais, 2003; von Mende, 2000). Riches and Curdt-Christianson (2010) have found that active parental participation with French immersion children was beneficial, particularly in literacy development, while Alvarez (2018) and Cummins et. al. (2006) have found considerable value in establishing home-school connections in the interests of language and literacy learning. When schools prioritize connecting with their students' homes, parents become familiar with the program and gain a sense of participation in their child's education. As an example, the document Supporting Your Child's Success in French Immersion and Extended French Elementary Schools (Ontario Ministry of Education, 2014) offers guidelines for parents of immersion students, answers important questions, and highlights possible challenges. It sets the stage for parents to become more involved in the immersion classroom by familiarizing them with programming and classroom activities. Nevertheless, 
in spite of parents' willingness to engage in their child's French immersion experience, some parents often feel incapable of doing so because of a lack of linguistic fluency in French or both French and English (Au-Yeung et al., 2015).

Using technology as a tool to help establish home-school connections has proven to be useful in overcoming linguistic barriers and keeping parents engaged with their child's language and literacy development. As an example, Pomper (2017) noted the potential for incorporating languages other than English into reading resources and developed a multimodal literacy program in which learners and parents used an iPad to access resources at home. Books in English and French, as well as French audio recordings, were available, enabling non-French-speaking parents to track their child's reading and provide support where possible. Similar to the Storybooks Canada resource, such a program gives linguistically diverse parents insight into instructional methods used in the classroom, which can help them recreate these practices at home or use them as a starting point for creating new activities with their child. The L1 can play a crucial role in this resource by promoting clarity and understanding both at home and in the classroom. The multilingual capacity of the Storybooks Canada resource thereby creates space for affirming linguistic identities of learners and their families, extending pro-active welcoming gestures, and cultivating a sense of belonging (Cummins et al., 2005).

\section{Research Design}

\section{Research Site}

To investigate the two research questions, the researchers partnered with a K-6 French immersion school in an inner-city community of Calgary, a city located in western Canada with a population of approximately 1000000 people. The partner school employed some 30 teachers and welcomed nearly 650 students in the 2018-2019 school year. The researchers did not examine the number of specific ethnicities or mother tongues present within the school in which the study took place. Nevertheless, available demographic statistics from the 19 communities that are part of the school attendance area provide a basis from which significant linguistic and ethnocultural diversity may be extrapolated. Although English was the most commonly reported mother tongue, speakers of mother tongues other than English or French comprised between $12 \%$ and $53 \%$ of the attendance area communities, with Cantonese, Mandarin, Spanish, Tagalog, and Arabic most commonly reported (City of Calgary, 2019). French mother tongue speakers reflected between $1 \%$ and $3 \%$ of the population. The partner school is one of 11 schools within the school district offering early French immersion, whereby learners enter in Kindergarten or Grade 1, and French is the sole language of instruction to the end of Grade 2. All classrooms are equipped with Internet access, and teachers routinely integrate online learning resources and activities.

\section{Method}

Drawing on Duff (2008), we chose the case study method for our research because it enabled us to address our two research questions using a rich narrative that captured nuance and complexity (Yin, 2018). Further, the use of case study lays the groundwork for 
future research agendas, frameworks, and models, particularly in first and second language acquisition research projects (Duff, 2008). The case study was framed within existing curricula and classroom planning objectives. Participating teachers were encouraged to inform the research by using Storybooks Canada as a learning resource in their classrooms, and by considering how it might be used to strengthen home-school connections. The teacher group functioned as a community of practice (Pyrko, et. al., 2016) around the use of Storybooks Canada, and meetings bringing teachers together to discuss their experience served to tap into how they used the resource to leverage the linguistic diversity of their multilingual classrooms. The teacher group enabled an iterative, practice-focused dialogue with the parallel aim of promoting collaborative engagement between teachers and researchers. The principal objective was to support teachers such that their participation would be useful to both the linguistically diverse school and the community.

\section{Participants}

The qualitative case study comprised one kindergarten teacher (Tara), two Grade 1 teachers (Maria and Victoria), and two Grade 2 teachers (Rochelle and Sara) ${ }^{4}$. Among students in the participating $\mathrm{K}-2$ classes, the most common first languages, in addition to English, included Mandarin, Arabic, and Slovak. While a breakdown of the exact numbers in each linguistic group was unavailable to the researchers, the existing range of L1 languages in the classroom was adequate for the purposes of our study. The participating morning and afternoon Kindergarten classes had 17 and 19 students; Grade 1 classes had 23 and 24 students, and Grade 2 classes had 21 and 20 students. The six participating teachers' first languages included French (3), English (1), Bafang (1), and Ukrainian (1). All participating teachers spoke both English and French fluently. Teachers described their interest in participation in terms of the opportunity to explore a new French-language resource that acknowledges the multilingual learners present in their classrooms. They emphasized that resources well-adapted to multilingual French immersion learners are difficult to find and discovering Storybooks Canada provided an exciting opportunity for students to connect with different languages, particularly in the home, while learning French.

\section{Procedure}

The study took place from February to June 2019. It included five teacher meetings conducted in both French and English. In the initial meeting, the researchers introduced Storybooks Canada to the participating teachers, and a projector was used to demonstrate the key functions of the site and how it works as a resource. In a subsequent session, teachers were introduced to the ways the resource could be implemented in their classes and how it is being used in other parts of Canada. While researchers took notes in the first meeting, subsequent visits were audio recorded and transcribed. A questionnaire was also used to capture information, such as which stories and design features teachers used and any pedagogical insights or reflections that may not have been covered in group conversations.

Adopting an iterative approach in successive teacher conversations enabled both teachers and researchers to reflect on the teachers' classroom experiences with their 
multilingual students and consider possible new applications of Storybooks Canada. Teachers brought some examples of student work to the meetings in order to demonstrate what students had accomplished. Some teachers also invited the researchers to come to their classrooms so the researchers could see more student exemplars on the walls. For example, the kindergarten teacher, Tara, had some vocabulary development and student work on the wall that she shared with one researcher, describing how she had woven them into a lesson that included some of the Level 1 Storybooks Canada books. This work was photographed and the photos were used as data that captured how lesson plans were created. No formal lesson plans were shared with the researchers, although they were described during the meetings. The researchers were able to develop three lesson plans based on the Storybooks Canada learning activities that the teachers had designed, and these lesson plans were sent to the participating teachers at the conclusion of the study. The teachers also sent the Storybooks Canada link home so that the students and their parents would have the opportunity to interact with the platform as an enhancement tool in their French immersion literacy journey.

\section{Data Analysis}

Using qualitative analysis and a collaborative approach, researchers and participants worked together to identify Storybooks Canada's affordances for French immersion, literacy engagement, and home-school connection. The researchers worked with the teacher participants, focusing on conversations represented in the transcripts of their meetings, which captured teachers' discussion of lesson plan structure and implementation experience. Photographs of learning artifacts provided contextualization and illustrated teachers' experiences and student engagement. In addition, the researchers referred to the teachers' comments drawn from the questionnaire, which became central to the analysis, and included discussions about teachers' use of Storybooks Canada in the classroom and its potential for use in the home. The entire process can be described as a thematic analysis, where we closely examined the data and identified common themes relating to topics, ideas, and patterns of meaning that came up repeatedly within the data (Braun \& Clarke, 2006).

We based our analysis on the nature of informal, organic, iterative processes that seek to uphold the highest degree of responsiveness. This is where narrative thematic analysis played an important role, permitting us to notice patterns in observances shared with us by the teachers and to develop analytic points drawing from narrative extracts that become illustrative when considered together (Braun \& Clarke, 2006; Reissman, 2008). This included analyzing written transcripts and learning artifacts, all of which contributed to our analytic narrative. The researchers completed individual analyses first and then came together to establish a consensus on the themes identified.

\section{Findings}

In addressing our two research questions, we were particularly interested in which design features of Storybooks Canada held the most appeal for French immersion pedagogy, and how the platform might serve the dual function of supporting literacy 
engagement while validating and leveraging the diverse home languages of children in French immersion programs.

\section{Research Question \#1: Storybooks Canada and French Immersion Classrooms}

Our first research question was "What features of the Storybooks Canada digital platform can help promote literacy engagement in early French immersion programs?" Drawing on the qualitative data, the researchers identified five features of Storybooks Canada that were particularly appealing for teachers in this context: (i) The multilingual features, (ii) the ability to project a story on a large screen, (iii) the audio component, (iv) the illustrations, and (v) the different levels of text difficulty. Teachers described classroom experiences with these features of Storybooks Canada and also speculated about the potential use of some of these features to promote home-school connections. The researchers divided the findings into five themes based on the five features of the resource that teachers found most pertinent to their practice. The features were associated with the themes of literacy engagement, text comprehension, learner autonomy, meaning-making, and instructional differentiation.

\section{Strengthening Literacy Engagement in a Multilingual Context}

Although the teachers were principally focused on French-language education, they noted that the multilingual features of Storybooks Canada could promote literacy engagement for their linguistically diverse students. For example, if a student was having problems achieving a satisfactory level of literacy engagement, teachers noted that the Storybooks Canada platform enables students to change the language of the story they are reading, giving students the opportunity to better comprehend and engage with the story in a familiar language. This also helps to reduce the isolation that a newcomer student might feel if she or he does not yet read or understand French or English. Rochelle commented:

When kids are immigrating from other countries and maybe they do not have English as a second language, or they barely speak any English or French, so then it is very hard for them to understand books or have that base, especially if I do not know their first language. So, I think that would be an interesting resource to have with them so that they could maybe read the book once in their native language, and then we could work on the vocabulary in French or English depending if they were going to a French or English school. So, I could see it that way, and then helping parents support their kid at home as well.

This observation exemplifies a useful way in which teachers could incorporate languages other than English in the French immersion classroom, and harness the multilingual knowledge of students. Such findings are consistent with Cummins (2014) and Lapkin (2000) whose research builds on the power of the L1 to help in the development of the L2 and supports Ballinger's (2013) and Lyster's (2013) views that students can benefit from making cross-linguistic comparisons in becoming biliterate/multiliterate. 
Rochelle added that student access to stories in their home languages read in French at school may contribute to a sense of self-efficacy and pride in their identity:

I could also see it as something students could show to other kids to elevate their first languages; they could use it to read a story to other kids in class to be proudokay maybe they do not know English or French, but here is what I do know.

Such data lends support to Madi and Garbadi's (2014) research, which affirms the value of a student's L1 in the language classroom. It also supports the view that learner identity needs to be affirmed in order to support students' literacy engagement (Darvin \& Norton, 2014).

\section{Facilitating Text Comprehension and Engagement with Large Screen Projection}

The digital nature of Storybooks Canada allows for projection on a screen or wall, which Moulton (2006) has reinforced as an innovative way of learning everything from Geography to Math. Its usefulness is explained in that everyone in the class can simultaneously see and engage with the text and illustrations at the narrative level and at the word level. As Victoria said:

It's so nice that you can project it. Whenever we read a book in the class, it is never big enough for everybody to see at the same time or see the same thing. So this way, it is so helpful to have the big picture. Everybody can see, and they all see the same thing at the same time. They don't have to move around to see or pass the book.

Further, by projecting the story in French on the screen, the teacher and students can follow the sounds of the text with an indicator on the screen and link these with the corresponding images of each story. To illustrate this, Rochelle commented: "You can highlight the words with your mouse as you are reading it, so they know exactly which words you are reading and read along." The kindergarten teacher, Tara, was able to focus on vocabulary activities, with emphasis on enunciating letter and syllabic sounds in French.

The versatility of the platform was a particular strength, according to Maria: "The fact that you can use it online, or on the screen, or have the hard copy of it makes it more versatile, depending on how you want to use it - as a whole class, small group or individually." Rochelle also commented on the digital versatility:

And I find, too, because you can access the same resource multiple times, you can go a little deeper with stories. Because library books - you have to return them. Or you don't have activities to go with them. Whereas this it is all nicely together. Easy to find.

The use of the large screen created a simultaneous learning opportunity for all students that promoted literacy engagement. It helped the teachers to see immediately how the students responded to the stories, what new vocabulary students needed to learn, and how to help students with the pronunciation of new words. 


\section{Increasing learner autonomy with the audio component}

Audio literacy can be defined as having the ability to listen to and comprehend information that is shared through sound waves. Not only can visual images help students in their literacy learning, but audio can help students hear the word being pronounced (Jabr, 2013). Audio functionality, including autoplay, in which the audio is accompanied by highlighting in the text, was emphasized as a rare and especially useful feature of the Storybooks Canada platform. Autoplay can be adapted for whole class and individual listening and reading, as well as for individual and family-supported listening and reading at home. As Rochelle said:

One thing that it makes me think of is, especially for children who have a hard time reading alone [or are coming to class with a different L1], they are more confident and comfortable. Often, I cannot read with every student a book before I get them to try it out on their own, so this maybe gives them that pride because they have heard it once and then they can try. And then if they make a mistake, they can try to listen another time. It can give them that independence.

Grade 2 teacher participants described two instances of students requesting or pursuing an English language audio story version. When Sara's class was being introduced to the story, the students were enthusiastic and asked to hear it in English. Sara asked what the students thought about using the resource at home, and they responded enthusiastically. She showed them that it was possible to read and listen to the stories at home:

They really liked this idea and they wanted to listen to English in class. I showed them how to read and listen in English at home...For Grade 2 many students were in a hurry to read in English and listen to the reading in English. They were super excited about the idea.

In another example, Rochelle prepared a listening station with the language setting on French. Upon checking in with the group at the listening station, she found the students listening to stories in languages other than French — stories that were above their reading level. Although this finding did not align with the intended outcomes of the learning activity, it suggests that students were intrigued by the resource and often selected their home language to listen to the stories. This practice presented the teacher with the opportunity to encourage students to go back and listen to or read the stories in French after they had read the story in their home language.

With respect to this theme, Rowsell (2019) provided useful insights into our findings: she argues that teachers need a framework that offers not only different methods of teaching with technology but also methods that enrich connections and relationships with students. The audio feature of Storybooks Canada helped teachers and students feel more confident with their teaching and learning, and also served as a resource to promote literacy engagement in both the home and the school. 


\section{Using Illustrations for Meaning Making}

The process of literacy engagement has shifted in recent years from the use of exclusively print-based material to a more digital platform (Razfar \& Yang, 2010). In the course of the study, we found that digital stories were perceived to be more engaging than print because of the multimodal design features that give the reader more interactive options (Gilman \& Norton, 2020). Further, the stories represented in Storybooks Canada included a large variety of illustrations to help the reader understand more fully the text they were encountering. Such digital innovations can be used to support and develop literacy skills with multilingual students as well as those who are struggling readers (Darvin \& Norton, 2014; Hare et al. 2017).

All the teachers found the illustrations in the stories helpful for meaning-making, language learning, and vocabulary development. Maria, for example, noted as follows:

They have the visual because it highlights the words at the same time. I really like [this feature] because in Grade 1 we also work on storytelling, the narrative piece, sequential stories, so I used the images a lot. And it's easy to print out, so I was able to use the images in booklets where students could use the images to tell the story orally.

One of Storybooks Canada's features, the wordless story, with images only, proved to be a particularly powerful instructional aid for the teachers. Teachers commented on the potential these wordless stories could have with respect to their linguistically diverse students. They found that students could draw on their L1 as they envisioned the plot of the story and then be encouraged by the teacher to re-create the plot in French. As noted by Sara:

I really like the fact that I could use the wordless version to just get my students to be creative and, at the end, to read the story and see what the story is about. At first, I let them create, [based on] the image, their own story. And at the end, they find out the actual story. Some of them felt like they wrote the story.

Another Grade 1 teacher, Victoria, used the wordless picture book for a vocabulary activity, with students responding orally to what they saw and identifying elements of the images. As she noted, this activity provided an entry point into predictions of what the story was about and helped to scaffold the subsequent reading as a class:

I showed them the wordless version and I asked them what they saw. They needed to respond using "I see...." and describe the image and try and respond in French to practice their vocabulary. Next, I showed them the version with words and I read them the story in French. I then asked them the difference between what they had read and what they saw and whether the two activities were the same or different. I asked them why they were similar or different. The first time they found the activity challenging. 
Asked how students were engaging with the images, Victoria explained that they participated attentively, unpacked the details and gradually developed more complex sentences, drawing on prompts:

Yes, they noticed a lot of things, lots of details like whether the animals were in the jungle or near the lake, they were looking for details. I think it helped them develop more vocabulary than I thought and they were able to construct full sentences. I was really surprised today... like, 'Oh I see the boy who is wearing yellow sweater' for example is a more complicated sentence than 'I see a boy' that many of the students frequently use. So, it helps make longer and more complex sentences.

Some students were also active in creating their own image texts. Further into the study, with the help of a downloadable imageless storybook, Victoria facilitated the creation of a Story Wall with a Grade 1 class, whereby students created illustrations that corresponded to the text of each page of the story. Victoria subsequently affixed the illustrations above the corresponding text on the wall to encourage spontaneous rereading of the story, familiarization with the story's vocabulary, and engagement through participation in the Story Wall creation. In a final example, Maria found images on the digital platform helpful for vocabulary development:

We would use them all together to work on vocabulary. So, one was Regardez les animaux [about farm animals]. We brought out all the new vocabulary that we knew in that first picture where it had everything, and then the students go [back to] the pictures after, to tell the stories.

Rowsell (2019) observed how illustrations in a text can be used to engage, interact, and socialize with others, something that occurred frequently in the Storybooks Canada project. In addition, White $(2011$, p. 3$)$ notes that 'art renders back to us not simply what we see, but how we react to what we see and what we know as a consequence of that seeing'. Illustrations, whether made available to students or produced by students, are thus central to the promotion of literacy engagement in the French immersion classroom.

\section{Providing Instructional Differentiation with Leveled Texts}

Storybooks Canada's 40 stories have increasing levels of text difficulty, ranging from $1-5$, which enables the teacher to direct students to texts with appropriate levels of difficulty. This is especially useful to accommodate the different reading levels of learners and is characteristic of most classrooms. During the study, Rochelle described the organization of the storybooks (according to reading level) and the teacher link as "pure gold" for quickly finding stories that could work for the class. As she said:

I had seen on the website where you have the links, and as a teacher to find that, that is like gold, because if you want to teach a specific thing, . . . you can read that one instead of reading every single one. 
The feature also enables students to read independently, at a range of different levels, as well as in small groups. This permits instructional differentiation for literacy practices in classrooms that serve diverse learners (DelliCarpini, 2011, Roessingh, 2018). Sara noted, for example, that the different levels enabled her to provide stories for children at different stages of French language development. For students who struggled with reading, some focused on listening to the stories, while others read in groups of three to four students:

I was giving them a choice to start by Level 1, because some of them are on Level 2 , to be comfortable reading those books. Some of my students were using Levels 2 and 3, but the rest were using Level 4 and just a little bit 5. So, I really like the fact that I had different levels.

Research has found that multimodal stories that incorporate the L1 of the learner with levelled texts can also be used to bridge home and school literacy practices (Lotherington, 2011). The functionality of Storybooks Canada to promote literacy engagement with the same story in multiple languages or different stories in the same language at multiple levels can help linguistically diverse students navigate a range of texts in both the school and the home.

\section{Research Question \#2: Storybooks Canada and Home-School Connections}

We had a range of intriguing findings with regard to our second research question, "to what extent did the teachers think that Storybooks Canada could strengthen connections between linguistically diverse homes and schools?" The teachers all agreed that most parents want to help their children at home but do not know how best to proceed. In light of the larger context of English language dominance in the wider community, French immersion teachers (in Calgary) have noted that there is an overall lack of materials that can help linguistically diverse parents to engage with their children's French language learning. Maria said, "In my opinion, being in a French immersion school and teaching a second language, there are not a lot of resources. It's really difficult." Similarly, Victoria noted, "Coming from a francophone background I never realized how the level was so much higher than what the students were capable of understanding in immersion and that's really a challenge."

The teachers highlighted the freely available multilingual capacity of Storybooks Canada as a feature that could strengthen home-school connections. As Sara noted:

It's helpful for teachers, but for parents as well. I can use one story if I have maybe a student who is struggling with reading or something like that, [and] I can send the link to the parent in the mother language and maybe the parent can read or help at home.

Sara noted further that parents could be encouraged "just to use your mother language to explain the story at home, to get the child to use the vocabulary that maybe they do not know, or do not use here with the French language." As an example, in one of the lesson plans, the teacher began a group reading exercise in which the class read the first four pages of a story together, and then the students were given until the next day to discuss 
with their parents and peers some of the predictions for the next part of the story. This presented the opportunity for the students to go home and read the story in the L1, while at the same time discuss with their parents the questions that were brought up in the classroom.

The audio feature, similarly, could strengthen home-school connections. As Maria, the Grade 1 teacher, noted:

I think it's really great. I really do like the audio part of it, to use as a whole class, and even in small groups, or individually. I think it is really a great feature for the students at school and also at home to have that exposure to the French language because often when parents ask, "How can I help my student?" That's something that we can tell them to do, to listen. And then they have the visual because it highlights the words at the same time.

Teachers noted the Storybooks Canada platform also provides wordless storybooks in its portal, which would be helpful if the child's mother tongue is not included among the languages on the Storybooks Canada site. Maria indicated that parents could use the wordless storybooks to help their children with writing:

I think parents sometimes do not know how to support their kid with writing, especially at home. And that can be one way that they can help the student. So if you tell parents, 'You can print this out, the wordless story, and help the child to write a story', they can build up their vocabulary base. That way they have somewhere to start.

These findings are important in that immersion programs in Canada typically do not provide for learning through a student's home language if it is different from the program's two instructional languages of French and English. As such, Storybooks Canada offers free home language support and corresponds well with research on the value of home-school connections for learners whose home language is neither French nor English (Dagenais, 2003; Swain, et al., 1990; von Mende, 2000).

Although Storybooks Canada has much potential for strengthening home-school connections, teachers expressed hesitation about the social and cultural content of some of the stories. As Sara noted, "Some of the stories were just too sad. I enjoyed it, but I didn't feel comfortable seeing some of the stories with my students just because of that." She noted further:

Some parents also found some of the story content challenging. I am trying (to encourage use of Storybooks Canada at home) with one of my parents, you know, and she likes it, but she told me that she wasn't really sure about some of the stories. She didn't understand some of the stories. We talked about the fact that sometimes you need to be in that context to understand what is going on.

Rochelle and other teachers noted that cultural representations in some of the stories would benefit from scaffolding, particularly where the cultural differences might be perplexing. Some stories depicted cultural content such as traditional clothing, hairstyles, places, foods, 
and relationship interactions that might require additional explanation to facilitate comprehension. Other teachers noted, however, that the distinctive cultural features of the stories might be transformed into teachable moments that can make strong home-school connections. As Victoria noted:

In my class, we did Counting Animals (Buthelezi et al., n.d.), and one of my students was particularly really happy about it because she comes from Pakistan. And she was like, 'Oh, well, I see lots of different animals that maybe you guys never saw before,' and she started to talk about these different animals. And then the other one just added on about different animals. And it is a big part of the curriculum in science in Grade 1, so we just had a big discussion about it — with this site they really enjoyed; they can always find all the things that are important for them in the stories, and then talk about their own events. I think it makes them more secure to talk about it because, well, "We saw these animals that are in Africa, so I come from another place, and I saw other things. So, I can talk about it like everybody is talking about the bears."

Victoria's response to her Pakistani student is a compelling example of a teacher who is responding sympathetically to the needs of a diverse student population and adopting instructional practices that situate the teacher in a more interactive relationship with students and their cultural knowledge, as advocated by Lyster (2008) and Rowsell (2019). Another example that one teacher brought forward included a lesson on animal sounds and how they are differently expressed in different languages. Through this discussion, students who spoke different languages in the class were able to draw upon their mother tongue and contribute to the class in a delightful and non-threatening manner. Although examination of the cultural content of the stories was beyond the scope of our study, there is clearly much potential for further research on this topic, particularly as regards the potential of culturally diverse stories to strengthen home-school connections.

It is important to note, however, that while the teachers all agreed that the multilingual capacity of Storybooks Canada was a useful resource in the home, they did not focus on this feature for classroom use. Consistent with findings from Germain's (1991) and Calvé's (1991) work, the teachers generally advocated a more traditional French immersion approach, emphasizing the importance of maximizing exposure to the French language as learners developed their nascent French vocabulary: "Our objective is to provide lots of vocabulary as early as we can," said Tara. Several teachers described the responsibility they have for preparing students to develop language strategies that do not overly rely on translation and, in particular, English translation. One teacher, Sara, expressed concern that insufficient French language confidence at the Grade 3 level could lead to loss of motivation as English is introduced:

It's true that in our case we are only responsible for French. In my case, I am only responsible for French. Anything that's in English I send it home. It's true that we can practice translanguaging strategies, but we don't want these students to think that all the work being done in class can be done in English. In their second and third year, they will all be learning English as well. 
In sum, teachers were reluctant to use English, or any other language, for learning French in the classroom. Such practices were perceived to be inconsistent with their French immersion pedagogical approach, which recognizes that English is the dominant language (in Calgary/Canada) and that priority should be given to the French language in the French immersion classroom. However, teachers did see the potential uses of Storybooks Canada's multilingual features for the linguistically diverse home, and how crosslinguistic practices in the home could strengthen connections to linguistic practices in the French immersion classroom.

\section{Discussion}

Within the context of immersion and language learning, there is a dearth of research on the effectiveness of using freely available multilingual digital books to promote literacy engagement and to build home-school connections, particularly within linguistically diverse school settings. The findings from our study suggest that French immersion teachers enjoyed using the French language version of the Storybooks Canada platform to create a range of interactive activities for their students that involved reading, writing, listening, and speaking components, and, in so doing, encouraged text comprehension and literacy engagement. Teachers found the platform to be accessible, user-friendly, and generally intuitive and appreciated that it is free for all to use. The teachers particularly embraced the visual, audio, and wordless features of the Storybooks Canada platform, and found the downloadable option very appealing. While noting that not all the stories depict children in safe, happy, or familiar environments, teachers drew actively on Storybooks Canada in ways appropriate for learners' grade and interest level. With more time for integration from the beginning of the year, Storybooks Canada could become, as Maria noted, "a very important resource" for the French immersion classroom.

It is important to note, however, that the teachers were reluctant to use the multilingual features of Storybooks Canada within the French immersion classroom context. While they recognized the need to leverage the linguistic expertise of children and their families to strengthen home-school connections, particularly in home languages that are not instructional languages in the school context, they were hesitant to incorporate other languages in their classroom activities. This debate over the use of L1 in the immersion classroom is far from being settled. Yadav (2014) recognizes the consternation that language teachers feel over the use of L1, some espousing it, some dramatically overusing it, and others eschewing it. Nonetheless, using the linguistic capital of the immersion student can be advantageous, particularly when taking into consideration the learners' mother tongue and cultural background, and incorporating them to leverage students' learning (Yadav, 2014). Some researchers call this 'translanguaging' or the process whereby the language learner can use their own language(s) as an integrated communication system (Garcia, 2009). Translanguaging enables students to access different linguistic features of their mother tongue, in order to maximize communicative potential (Garcia, 2009). Current research suggests that multilingual language learners can benefit greatly from translanguaging as a pedagogical approach; however, more research is required to determine how it can best be applied to early French immersion classrooms.

In spite of their reluctance to use home languages in the classroom, the teacher participants considered the multilingual features of Storybooks Canada as having much 
potential for strengthening home-school connections. Teachers made compelling recommendations for ways in which linguistically diverse parents could use the platform to support their children in learning French as well as strengthening the home language. Teachers noted that parents and children could listen to stories together in the home language and in French, and they could recreate stories in wordless texts and discuss vocabulary items in preparation for classroom activities. For example, with reference to some of the more advanced stories such as Magozwe (Koyi, n.d.), the flexibility of the language toggle tool, with the multilingual capacity of the platform, enables the story to be previewed (and revisited) at home with a family member to promote literacy engagement, with opportunities to respond affectively to the content. In addition, the wordless text enables parents to scaffold language learning and meaning-making. This suggests much promise for responding to the needs of linguistically diverse student populations and their communities.

The researchers also found that using Storybooks Canada gave students from different parts of the world the opportunity to learn from one another about a range of topics, thus building relationships between students, as recommended in culturally responsive pedagogy. For example, in "Counting Animals", while one student observed an animal that was unfamiliar in Canada, another student from Pakistan was able to identify a number of animals as common in Pakistan, thus opening up their worlds to the classroom. This provided a comfort level to the students, knowing that it was acceptable to talk about animals from their home countries. This broadened the scope of what students think is possible to discuss in French immersion classrooms.

Beyond Canada, research is beginning to emerge on the way Storybooks Canada's sister sites on the Global Storybooks portal can promote literacy engagement for language learners. In the United Kingdom, for example, Storybooks UK is being used to promote inclusive education in multilingual classrooms where German, French, and Spanish are taught as modern languages. Manion (2020, p. 70), for example, noted that all the stories in Storybooks UK represent "universal values", and she discussed the ways in which one of the German language stories, "Andiswa, Fußballstar" (Daniels, n.d) could be used to address issues of gender equality in the German language classroom. Similarly, YounieGillham (2020, p. 53) advocated strongly that "inclusion means enriching our classrooms and our schools", and described how the Spanish language story, "Cocinando" (Verbeek, Dladla, \& Buthelezi, n.d) engaged the attention of a young learner in her class:

To my delight, this story caught the attention of one EAL child. I could tell by his body language that he was curious, he was not chatting, he had turned towards the board and was paying attention. For the first time, I saw him engaged.

Such research suggests that teachers and parents can help language learners articulate responses to a story on an affective level, as well as make "connections between classroom language and the real lives of students on many levels, from the practical to the political to the aesthetic" (Yeoman, 1996, p. 600). 


\section{Conclusion}

Although immersion programs have had a huge impact, both nationally and internationally (Johnson \& Swain, 1997, Lyster, 2007), the world's changing demographics now demand further examination into the potential that a multilingual student brings to the immersion classroom and the resources that are needed to harness that potential. Our study suggests that (free) multilingual digital books that can help promote literacy engagement for linguistically diverse students would be welcome in both schools and homes. Further, as language learning pedagogy changes, plurilingualism is being recognized increasingly as a rich teaching and learning tool (Piccardo et al., 2022). Researchers are approaching this method of language learning with more confidence as they understand how students can use more than one language to communicate a given message at any one time. Further research will provide greater insight into the impact that the judicious use of home languages might have on immersion programs in both Canada and the international community (Ballinger et al, 2017; Lyster, 2019).

We look forward to future research that seeks to determine if multilingual digital resources such as Storybooks Canada can indeed help parents to become partners in their children's immersion education. Although print dual language books have a similar purpose, digital dual language books, particularly those that are multilingual and freely available, can provide innovative pedagogies such as toggling and audio, which our teachers found pedagogically appealing. Our study suggests that Storybooks Canada and other digital innovations are useful resources for both teachers and parents as schools seek to promote literacy engagement in immersion classrooms, strengthening connections between homes and schools and between linguistically diverse communities and nations.

Correspondence should be addressed to Rahat Zaidi.

Email: rahat.zaidi@ucalgary.ca

\section{Notes}

${ }^{1}$ https://www.storybookscanada.ca/

${ }^{2}$ https://globalstorybooks.net/

${ }^{3}$ https://africanstorybook.org/

${ }^{4}$ Pseudonyms are used.

\section{References}

Alvarez, A. (2018). Drawn and written funds of knowledge: A window into merging bilingual children's experiences and social interpretations through their written narratives and drawings. Journal of Early Childhood Literacy, 18(1), 97-128. https://doi.org/10.1177/1468798417740618

Asara, W. (n.d). Chicken and Millipede (M. Brink, Illus.). Retrieved September 15, 2019, from the Storybooks Canada website: https://storybookscanada.ca/stories/en/0141/ 
Au-Yeung, Karen, Hipfner-Boucher, Kathleen, Chen, Xi, Pasquarella, Adrian, D'Angelo, Nadia, \& Hélène Deacon, S. (2015). Development of English and French language and literacy skills in EL1 and EL French immersion students in the early grades. Reading Research Quarterly, 50(2), 233-254. https://doi.org/10.1002/rrq.95

Ballinger, S. (2013). Towards a cross-linguistic pedagogy: Biliteracy and reciprocal learning strategies in French immersion. Journal of Immersion and Content-Based Language Education, 1(1), 131-148. https://doi.org/10.1075/jicb.1.1.06bal

Ballinger, S., Lyster, R., Sterzuk, A., \& Genesee, F. (2017). Context-appropriate crosslinguistic pedagogy. Journal of Immersion and Content-Based Language Education, 5(1), 30-57. https://doi.org/10.1075/jicb.5.1.02bal

Braun, V., \& Clarke, V. (2006). Using thematic analysis in psychology. Qualitative Research in Psychology, 3(2), 77-101.

Busch, B. (2012). The linguistic repertoire revisited. Applied Linguistics, 33, 503- 523. https://doi.org/10.1093/applin/ams056

Busch, B. (2015). Expanding the notion of the linguistic repertoire: On the concept of Spracherleben-The lived experience of language. Applied Linguistics, 38, 340-358. https://doi.org/10.1093/applin/amv030

Buthelezi, Z., Dladla, T., \& Verbeek, C. (n.d.). Counting animals. Retrieved September 15, 2019, from the Storybooks Canada website: https://www.storybookscanada.ca/stories/en/0327/

Calvé, P. (1991). Vingt-cinq ans d'immersion au Canada 1965-1990 [Twenty-five years of im-mersion in Canada 1965-1990]. Études de Linguistique Appliquée, 82, 7-23.

Cenoz, J., \& Gorter, D. (2011). Focus on multilingualism: A study of trilingual writing. Modern Language Journal, 95, 356-369.

City of Calgary. (2019). Community profiles. Retrieved May 12, 2019, from https://www.calgary.ca/CSPS/CNS/Pages/Research-and-strategy/Communityprofiles/Community-Profiles.aspx

Clyne, M. (2011). Three is too many in Australia. In C. Hélot \& M. Laoire (Eds.), Language policy for the multilingual classroom: Pedagogy of the possible (pp. 174187). Multilingual Matters.

Cook, V. (2001). Using the first language in the classroom. Canadian Modern Language Review, 57(3), 402-423.

Creese, A., \& Blackledge, A. (2010). Translanguaging in the bilingual classroom: A pedagogy for learning and teaching? Modern Language Journal, 94(1), 103-115.

Cummins, J., Chow, P., \& Schecter, S. R. (2006). Community as curriculum. Language Arts, 83(4), 297-307.

Cummins, J. (2007). Rethinking monolingual instructional strategies in multilingual classrooms. Canadian Journal of Applied Linguistics, 10(2), 221-240. Retrieved September 15, 2019, from https://journals.lib.unb.ca/index.php/CJAL/article/view/19743

Cummins, J. (2011). Literacy engagement: Fueling academic growth for English learners. Reading Teacher, 65(2), 142-146.

Cummins, J. (2014). Rethinking pedagogical assumptions in Canadian French immersion programs. Journal of Immersion and Content-Based Education, 2(1), 3-22.

Cummins, J. (2019). The emergence of translanguaging pedagogy: A dialogue between theory and practice. Journal of Multilingual Education Research, 9(1), 13.19-36. 
Cummins, J., Bismilla, V., Chow, P., Giampapa, F., Cohen, S., Leoni, L., Sandhu, P., \& Sastri, P. (2005). Affirming identity in multilingual classrooms. Educational Leadership, 63(1), 38-43.

d'Anglejan, A. (1984). Language planning in Quebec: A historical overview and future trends. In R. Y. Bourhis (Ed.), Conflict and language planning in Quebec (pp. 2952). Multilingual Matters.

Dagenais, D. (2003). Accessing imagined communities through multilingualism and immersion education. Journal of Language, Identity \& Education, 2(4), 269-283.

Dagenais, D., Toohey, K., Bennett Fox, A., \& Angelpreet Singh, A. (2017). Multilingual and multimodal composition at school: ScribJab in action. Language and Education, 31(3), 263-282.

Darvin, R., \& Norton, B. (2014). Transnational identity and migrant language learners: The promise of digital storytelling. Education Matters: The Journal of Teaching and Learning, 2(1), 55-66.

Davis, S., Ballinger, S., \& Sarkar, M. (2019). The Suitability of French Immersion for Allophone Students in Saskatchewan: Exploring Diverse Perspectives on Language Learning and Inclusion. Canadian Journal of Applied Linguistics, 22(2), 27-63.

DelliCarpini, M. (2011). Supporting ELLs before, during, and after reading. English Journal, 100(5), 108-112. https://www.jstor.org/stable/23047813

Duff, P. A. (2008). Case study research in applied linguistics. Routledge.

García, O. (2009). Education, multilingualism and translanguaging in the 21st century. In A. Mohanty, M. Panda, R. Phillipson, \& T. Skutnabb-Kangas (Eds.), Multilingual education for social justice: Globalising the local (pp. 128-145). Orient Blackswan.

García, O., \& Baetens Beardsmore, H. (2009). Bilingual education in the 21st century: A global perspective. Wiley-Blackwell.

García, O. (2009). Education, multilingualism and translanguaging in the 21st century. In A. Mohanty, M. Panda, R. Phillipson \& T. Skutnabb-Kangas (Eds.), Multilingual Education for Social Justice: Globalising the local (pp. 128-145). New Delhi: Orient Blackswan

Gaudet, G. (2013). Using mobile technologies in French immersion classrooms: Enriching second language acquisition. AISI Journal, 2(2), 1-10.

Germain, C. (1991). Le point sur l'approche communicative en didactique des langues [Update on the communicative approach to language teaching]. Montreal, QC: Les Éditions CEC.

Genesee, F., \& Lindholm-Leary, K. (2007). Dual language education in Canada and the USA. In J. Cummins \& N. Hornberger (Eds.), Encyclopedia of Language and Education, Volume 5: Bilingual Education. Springer.

Genesee, F., \& Gándara, P. (1999). Bilingual education programs: A cross-national perspective. Journal of Social Issues, 55(4), 665-685.

Gilman, M. (2018). Using Storybooks Canada and other digital stories to honour diversity within the classroom. In D. Blazevich and B. Chi (Eds.), Enriching Community Through Story: Strengthening Voice \& Choice: English Practice Journal, 60(1), 2936. http://bctela.ca/wp-content/uploads/2018/09/BCTELA-2018-Eng-Pract-Jrnllowres.pdf

Gilman, M., \& Norton, B. (2020). Storybooks Canada, English language learners, and the school curriculum. BC TEAL Journal, 5(1), 1-18. 
Hare, J., Darvin, R., Doherty, L., Early, M., Filipenko, M., Norton, B., Soni, D., \& Stranger-Johannessen, E. (2017). Digital storytelling and reconciliation. In P. Tortell, M. Young \& P. Nemetz (Eds.), Reflections of Canada: Illuminating our opportunities and challenges at 150+ years (pp. 200-205). UBC Peter Wall Institute for Advanced Studies.

Hélot, D. C., \& Ó'Laoire, D. M. (Eds.). (2011). Language policy for the multilingual classroom: Pedagogy of the possible. Multilingual Matters.

Jabr, F. (2013). The Reading Brain in the Digital Age: The Science of Paper versus Screens. Scientific American. February 5, 2015, from: http://www.scientificamerican.com/article.cfm?id=readingpaper-screens

Johnson, K. E., \& M. Swain (Eds.). (1997). Immersion education: International perspectives. Cambridge University Press. DOI: 10.1017/CBO9781139524667

Koyi, L. (n.d.). Magozwe (W. de Jager, Illus). the Storybooks Canada website: https://www.storybookscanada.ca/stories/en/0262/

Ladson-Billings, G. (1994). The dreamkeepers. San Francisco: Jossey-Bass Publishing Co.

Lambert, W. E. (1984). An overview of issues in immersion education. InStudies on immersion education: A collection for United States educators, (pp. 8-30). Sacramento, CA: California State Department of Education.

Lamarre, P. (1997). A comparative analysis of the development of immersion programs in British Columbia and Quebec: Two divergent sociopolitical contexts (Unpublished doctoral dissertation). The University of British Columbia, Vancouver, Canada.

Lotherington, H., \& Jenson, J. (2011). Teaching Multimodal and Digital Literacy in L2 Settings: New Literacies, New Basics, New Pedagogies. Annual Review of Applied Linguistics, 31, 226-246. doi:10.1017/S0267190511000110

Lyster, R. (2007). Learning and teaching languages through content: A counterbalanced approach. John Benjamins Publishing Company.

Lyster, R. (2008). Evolving perspectives on learning French as a second language through immersion. In D. Ayoun (Ed.), Studies in French applied linguistics (pp. 3-36). John Benjamins Publishing Company.

Lyster, R. (2019). Translanguaging in immersion: Cognitive support or social prestige? The Canadian Modern Language Review, 75(4), 340-352

Lyster, R., Collins, L., \& Ballinger, S. (2009). Linking languages through a bilingual readaloud project. Language Awareness, 18, 366-383. https://doi.org/10.1080/09658410903197322

Lyster, R., Quiroga, J., \& Ballinger, S. (2013). The effects of biliteracy instruction on morphological awareness. Journal of Immersion and Content-Based Language Education, 1(2), 169-197. doi:https://doi.org/10.1075/jicb.1.2.02lys

Mady, C. (2012). Inclusion of English language learners in French as a second official language classes: Teacher knowledge and beliefs. International Journal of Multilingualism, 9(1), 1-14.

Mady, C., \& Garbati, J. (2014). Talking taboo: Use of students' first languages in a second language classroom. What works? Research into practice-Research monograph 51. http://www.edu.gov.on.ca/eng/literacynumeracy/inspire/research/WW_other

Manion, B. (2020, Spring). Storybooks UK - “Andiswa, Fußballstar”. EAL Journal, p. 70. 
McMillan, B., \& Turnbull, M. (2009). Teachers' use of the first language in French immersion: Revisiting a core principle. In M. Turnbull \& J. Dailey-O'Cain (Eds.), First language use in second and foreign language learning(pp. 15-34). Multilingual Matters.

Moulton, J. (2006, July 18). The power of the big screen: The digital projector makes instructional materials larger than life [Web log post]. https://www.edutopia.org/power-big-screen

Nantale, R. (n.d.). Simbegwire (B. Mitchley, Illus.). Storybooks Canada. https://www.storybookscanada.ca/stories/en/0052/

Norton, B., Stranger-Johannessen, E., \& Doherty, L. (2020, January 19). Global Storybooks: From Arabic to Zulu, freely available digital tales in 50+ language. The Conversation. https://theconversation.com/global-storybooks-from-arabic-to-zulufreely-available-digital-tales-in-50-languages-127480

Norton, B., \& Doherty, L. (2020). Global Storybooks for multilingual UK Classrooms. EAL Journal, Spring, 21-25.

Ontario Ministry of Education. (2014). Supporting your child's success in French immersion and extended French elementary schools: A parent guide. Queen's Printer for Ontario. http://www.edu.gov.on.ca/eng/literacynumeracy/parentGuideFrench.pdf

Otheguy, R., Garcia, O., \& Reid, W. (2015). Clarifying translanguaging and deconstructing named languages: A perspective from linguistics. Applied Linguistics Review, 6, 281-307. https://doi.org/10.1515/applirev-2015-0014

Otiendo, V. (n.d.). Holidays with grandmother (C. Groenewald, Illus.). Storybooks Canada. https://storybookscanada.ca/stories/en/0243/

Piccardo, E., Germain-Rutherford, A. \& Lawrence, G. (eds). (2022) The Routledge Handbook of Plurilingual Language Education. Routledge.

Pellerin, M. (2013). E-inclusion in Early French Immersion classrooms: Using digital technologies to support inclusive practices that meet the needs of all learners. Canadian Journal of Education / Revue Canadienne De L'éducation, 36(1), 44-70.

Pomper, M. (2017). Rethinking home-reading: Supporting early French immersion students and parents with meaningful home literacy programs (Master's thesis). University of Victoria, British Columbia, Canada. http://dspace.library.uvic.ca/bitstream/handle/1828/8019/Pomper_Megan_MEd_201 7.pdf? sequence $=1$ \&isAllowed $=y$

Posse, D. (n.d.). Is the use of the learners' mother tongue justified in the foreign language teaching? Unpublished manuscript.

Prasad, G., \& Lory, M.-P. (2020). Linguistic and Cultural Collaboration in Schools: Reconciling Majority and Minoritized Language Users. Tesol Quarterly, 54(4), 797822.

Pyrko, I., Dörfler, V., \& Eden, C. (2017). Thinking together: What makes Communities of Practice work? Human Relations, 70(4), 389-409.

Razfar, A., \& Yang, E. (2010). Digital, hybrid, \& multilingual literacies in early childhood. Language Arts, 88(2), 114-24.

Rebuffot, J. (1993). Le point sur l'immersion au Canada [Update on immersion in Canada]. Éditions CEC. 
Reissman, C. K. (2008). Narrative methods for the human sciences. Thousand Oaks, CA: Sage.

Riches, C., \& Curdt-Christiansen, X. L. (2010). A tale of two Montreal communities: Parents' perspectives on their children's language and literacy development in a multilingual context. Canadian Modern Language Review, 66(4), 525-555.

Roessingh, H. (2018). Unmasking the early language and literacy needs of ELLs: What K3 practitioners need to know and do. BC Teal Journal, 3(1), 22-36. https://ojso.library.ubc.ca/index.php/BCTJ/article/view/276

Rowsell, J. M. K. (2019). How We Live Now: Striving for Resilient Repertoires of Literacy. In A. Woods, \& B. Exley (Eds.), Literacies in Early Childhood: Foundations for equity and quality, (83-98). Oxford University Press, New York.

Roy, S. (2008). French immersion studies: From second-language acquisition (SLA) to social issues. Alberta Journal of Educational Research, 54(4), 396-406.

Roy, S. (2015). Discours et idéologies en immersion française [Speech and ideology in French immersion]. Canadian Journal of Applied Linguistics/Revue canadienne de linguistique appliquée, 18(2), 125-143.

Ryan, D. (2019, March 18). Spring break reads: 70+ great books for kids and teens, as recommended by librarians. The Province. https://theprovince.com/entertainment/books/spring-break-reads-for-kids-and-teensas-recommended-by-vancouver-area-librarians/wcm/46a1fd9f-a003-42ae-94ad48e098a57d02

Rymes, B. (2014). Communicative repertoire. In B. Street \& C. Leung (Eds.), Routledge Handbook to English language studies (pp. 287-301). New York, NY: Rouledge

Stranger-Johannessen, E., Doherty, L., \& Norton, B. (2018). The African Storybook and Storybooks Canada: Digital stories for linguistically diverse children. Language and Literacy, 20(3), 121-133.https://doi.org/10.20360/langandlit29413

Stranger-Johannessen, E., \& Norton, B. (2017). The African Storybook and language teacher identity in digital times. Modern Language Journal, 101(S1), 45-60.

Stranger-Johannessen, E., \& Norton, B. (2019). Promoting early literacy and student investment in the African Storybook. Journal of Language, Identity, and Education, 18(6), 400-411. DOI: 10.1080/15348458.2019.1674150

Swain, M., Lapkin, S., Rowen, N., \& Hart, D. (1990). The role of mother tongue literacy in third language learning. Language, Culture, and Curriculum, 3(1), 65-81. https://doi.org/10.1080/07908319009525073

Swain, M., \& Lapkin, S. (2000). Task-based second language learning: The uses of the first language. Language Teaching Research, 4(3), 251-274. https://doi.org/10.1177/136216880000400304

Swain, M., \& Lapkin, S. (2005). The evolving sociopolitical context of immersion education in Canada: Some implications for program development. International Journal of Applied Linguistics, 15, 169-185.

Swain, M., \& Lapkin, S. (2013). A Vygotskian sociocultural perspective on immersion education: The L1/L2 debate. Journal of Immersion and Content-Based Language Education, 1(1), 101-129. https://doi.org/10.1075/jicb.1.1.05swa

Turnbull, M., \& Dailey-O'Cain, J. (2009). Introduction. In M. Turnbull \& J. DaileyO'Cain (Eds.), First language use in second and foreign language learning (pp. 114). Multilingual Matters. 
von Mende, S. P. (2000). Stepping up parental involvement in a French immersion classroom (Master's thesis). Simon Fraser University, Burnaby, Canada. http://www.collectionscanada.gc.ca/obj/s4/f2/dsk1/tape3/PQDD_0010/MQ61508.pdf

White, K. (2011). 101 things to learn in art school. MIT Press.

Yadav, M. (2014). The role of mother tongue in second language learning. International Journal of Research, 1, 572-582.

Yeoman, E. (1996). The meaning of meaning: Affective engagement and dialogue in a second language. Canadian Modern Language Review, 52(4), 596-610.

Yin, R. (2018). Case study research and applications: Design and method (6th ed.). Sage.

Younie-Gillham, J. (2020). Using 'Storybooks Canada' in the classroom. EAL Journal, p. 52-53.

Yu, W. (2000). Direct method. In M. Byram (Ed.). Routledge Encyclopedia of language teaching and learning (pp. 176-178). Routledge.

Zaidi, R. (2018). A proposal for 21st century education: An introduction to dual language book reading (Vol. 6, KONECT Teaching Materials). Konect Project.

Zaidi, R. (2020). Dual language books: Enhancing engagement and language awareness. Journal of Literacy Research. Vol. 52(3) 269-292. https://doi.org/10.1177/1086296X20939559

Zaidi, R. \& Dooley, K. (2021). Digitizing dual-language book pedagogies in uncertain times. The Reading Teacher. Vol 74(4). 